\title{
Carcass of a bowhead whale (Balaena mysticetus) found in the lateral moraine of the Jemelianovbreen glacier, eastern Svalbard
}

\author{
IDA LØNNE and EVA FUGLEI
}

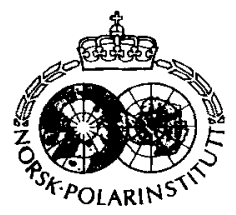
Lønne, I. \& Fuglei, E. 1997: Carcass of a bowhead whale (Balaena mysticetus) found in the lateral moraine
of the Jemelianovbreen glacier, eastern Svalbard. Polar Research 16(1), 9-18.
An $8 \mathrm{~m}$ long carcass of a bowhead whale (Balaena mysticetus) melted out from remnant glacier ice in the
lateral moraine of the Jemelianovbreen glacier in August 1996 . Folded and sheared sediment bands in the
ice suggest that the whale was incorporated during an advance of the glacier. The whale's longitudinal axis
was oriented parallel to the direction of the ice-flow, with the thinnest posterior part dipping upflow. The
posterior section was best preserved with muscles and blubber, although the entire skin surface was
strongly decomposed and only a thick fibrous surface was left of the blubber. The abdominal wall was
holed, most likely by marine organisms, and partly filled with a compacted mixture of well-sorted gravelly
beach sediments and fat. The whale seems to have been incorporated into the glacier together with
glaciomarine sediments and carried by the flowing ice to an altitude of ca. 15 m. Jemelianovbreen is a
tidewater glacier with two known surge-episodes. The first and most extensive of these occurred ca. 1900
AD and reached ca. $7 \mathrm{~km}$ outside the present coast-line. Radiocarbon dating of a fragment of a caudal
vertebra yielded $345 \pm 40{ }^{14} \mathrm{C}$ years BP (1535-1660 cal. AD), suggesting that the whale lived some time
during the last part of the cold period known as the Little Ice Age.

1. Lønne* and E. Fuglei, Norwegian Polar Institute, Svalbard Division, P.O. Box 505, N-9170 Longyearbyen, Norway. ('present address: The University Courses on Svalbard, P.O. Box 156, N-9170 Longyearbyen, Norway).

\section{Introduction}

Remnants of whales stranded on modern beaches are commonly observed in the Arctic, and radiocarbon dating of fossil whale bones from glacioisostatically raised beaches and from the sedimentary record constitute an important contribution to the Quaternary chronology of Svalbard (e.g., Salvigsen 1978; Forman 1990). In August 1996 a whale carcass melted out from glacier ice at the Jemelianovbreen glacier. The $8 \mathrm{~m}$ long carcass had survived the glacier transport in one piece, apparently without significant damage. Waves undercutting the ice have formed an almost vertical sea-facing cliff, exposing the deformation structures within the ice surrounding the whale.

A similar incident was reported from the Sveabreen glacier in Nordfjorden, central Spitsbergen (Dineley \& Garrett 1959). Remnants of a whale which was estimated to have been ca. $20 \mathrm{~m}$ long were found in the lateral moraine together with glaciomarine sediments with fossil molluscs. Unfortunately, only a brief description occurs from this finding (Dineley \& Garrett 1959) and the whale was never radiocarbon-dated (Dineley, pers. comm. 1996) (see discussion below).

The preservation of marine mammals in glacier ice is unusual. In the Jemelianovbreen findings, not only fossil bones but also flesh and muscles were preserved. In this paper we describe the geological and biological field observations and discuss the possible course of events, leading to the incorporation of the dead whale into the lateral moraine, and the timing of this episode.

\section{Geological setting}

The Jemelianovbreen glacier is a tidewater glacier located on the eastern coast of Spitsbergen (Fig. 1). The glacier has a total area of $95 \mathrm{~km}^{2}$, including the small tributary glacier Spælbreen (Lefauconnier \& Hagen 1991). Its frontal part is surrounded and underlain by Cretaceous to Tertiary bedrock (Dallmann et al. 1993), and the mountains south and north of the ice front reach an altitude of $500-600 \mathrm{~m}$ (Fig. 1). In 1990 the calving tidewater front was $4 \mathrm{~km}$ wide across the fjord basin; however, its position and shape have 


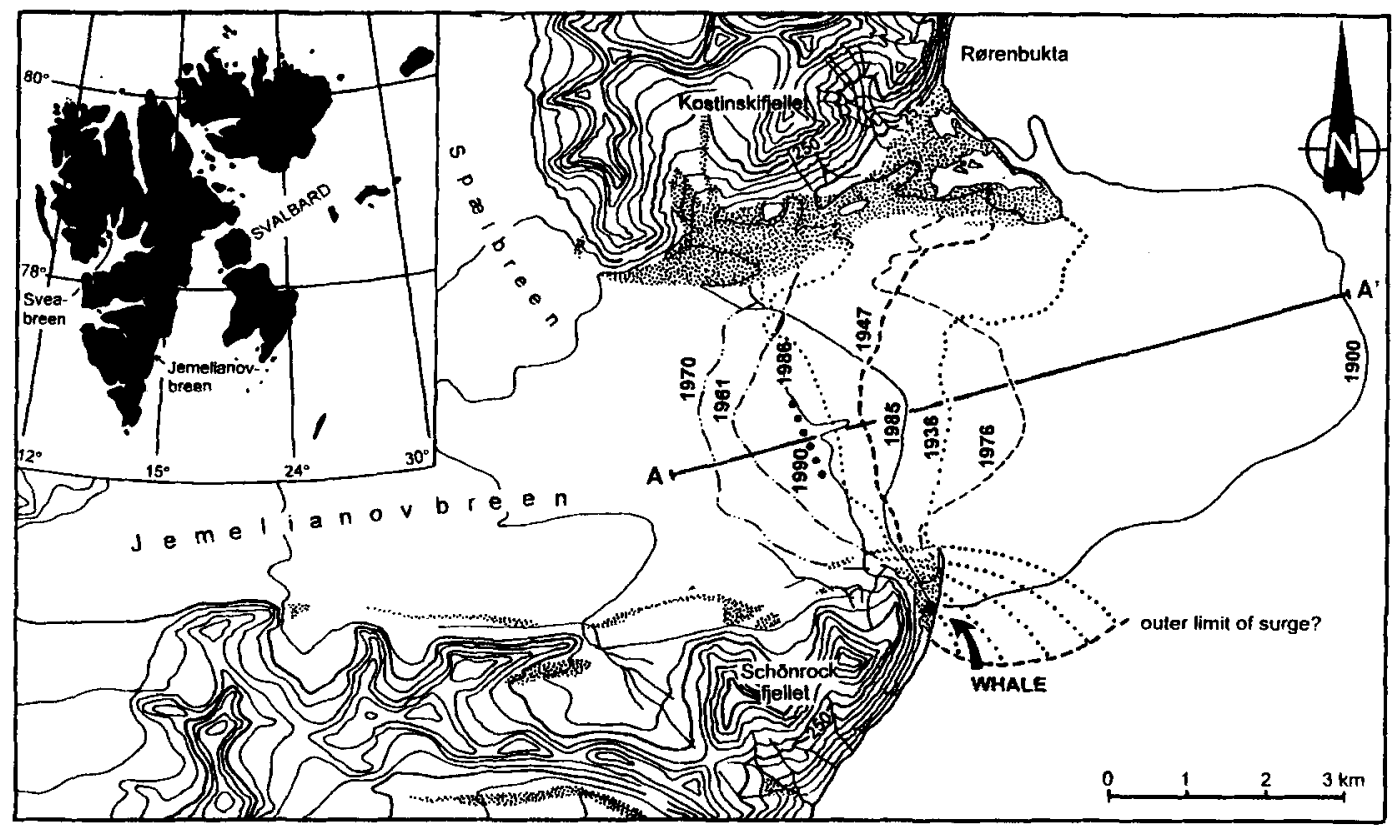

Fig. 1. The frontal part of the Jemelianovbreen glacier, eastern coast of Spitsbergen (see inset map). The position of the floating tidewater ice front in 1976 (Landsat image) is shown, as well as older known ice front positions from the period 1900 to 1990 (from Lefauconnier \& Hagen 1991, including the ice front position in 1990, as seen from aerial photograph $\$ 904037$, Norsk Polarinstitutt).

changed greatly (within a 9-km range) during the last 90 years (Figs. 1 and 2). The most extensive known position was mapped by the Vasiliev expedition in 1898-1902 (Vasiliev et al. 1907) and showed an ice-front position in 1900 which reached almost $7 \mathrm{~km}$ further east compared to the present coast-line (Fig. 1). The characteristic convex profile of the glacier in plan-view indicates that a glacial surge probably took place some few years before the expedition reached the area. Another surge occurred in 1971, reaching a position slightly more extended than seen on photographs from 1976 (see Fig. 1).

\section{Description}

The whale carcass

The whale carcass was positioned in the southernmost part of the Jemelianovbreen basin, close to the foot of the $541 \mathrm{~m}$ high Schönrockfjellet mountain. It was exposed in a vertical coastal ice-

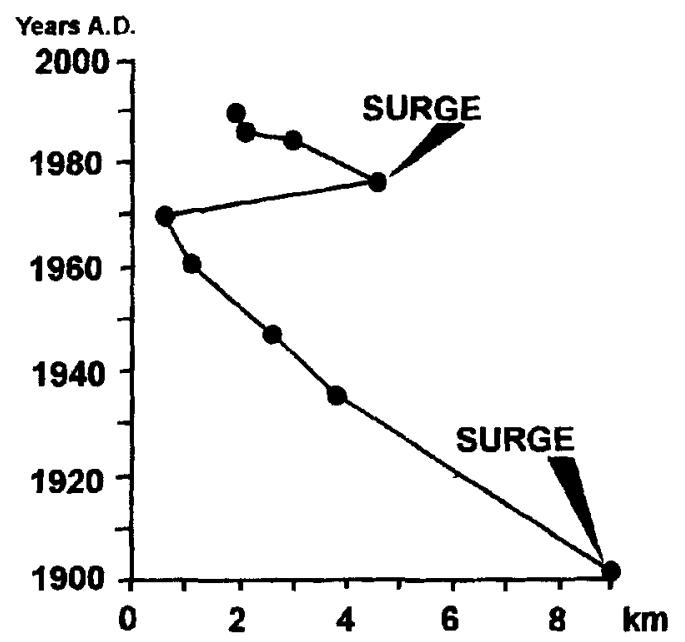

Fig. 2. Ice front movement curve (profile $A-A^{\prime}$ in Fig. I) showing fluctuations of the floating tidewater front of the Jemelianovbreen glacier. Two surges are recorded, ca. 1900 (the maximum extent of this was mapped by the Vasilievexpedition 1898-1902) and a second surge in 1971-1972 (Hagen et al. 1993). 

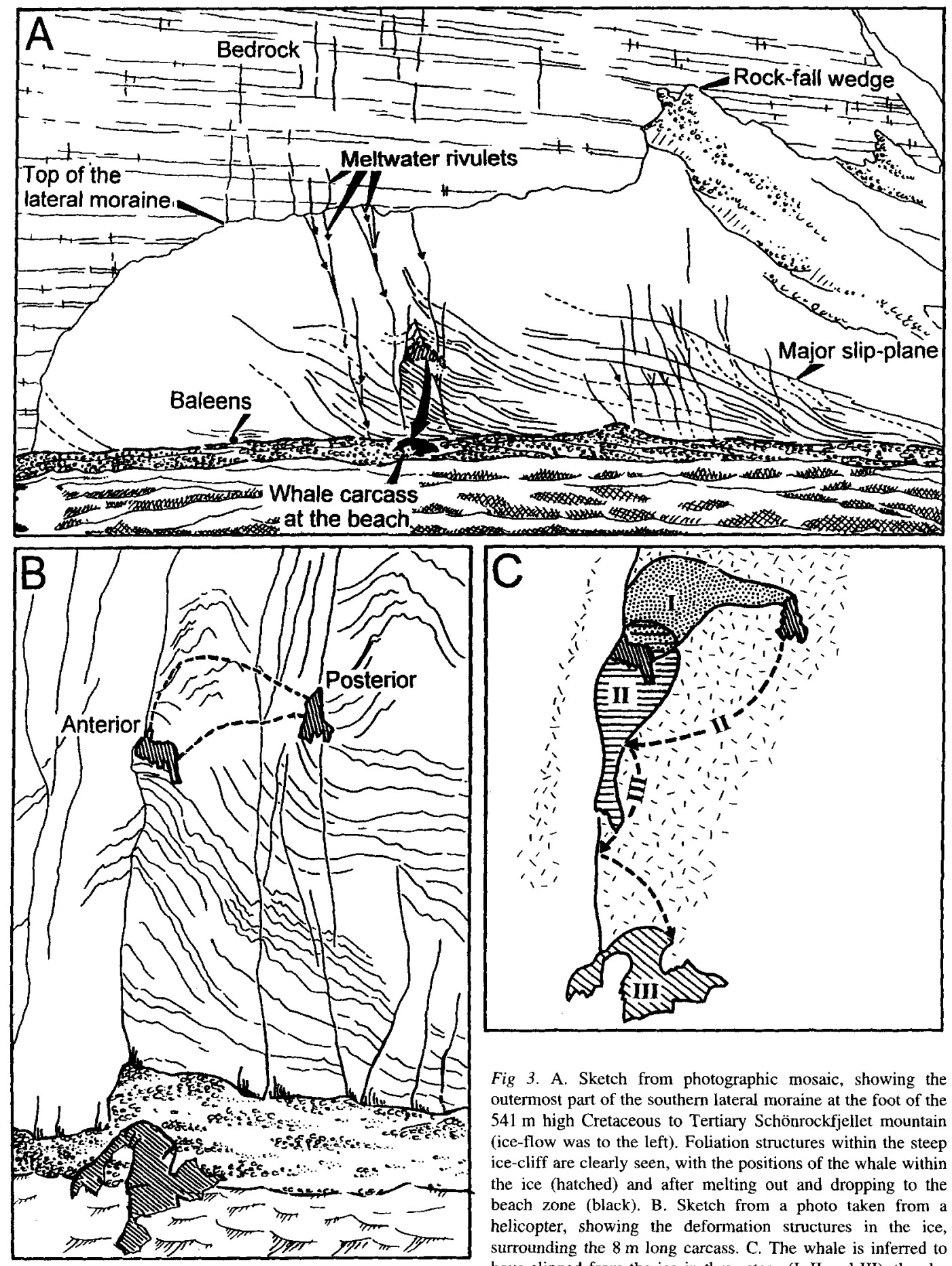

Fig 3. A. Sketch from photographic mosaic, showing the outermost part of the southern lateral moraine at the foot of the $541 \mathrm{~m}$ high Cretaceous to Tertiary Schönrockfjellet mountain (ice-flow was to the left). Foliation structures within the steep ice-cliff are clearly seen, with the positions of the whale within the ice (hatched) and after melting out and dropping to the beach zone (black). B. Sketch from a photo taken from a helicopter, showing the deformation structures in the ice, surrounding the $8 \mathrm{~m}$ long carcass. $\mathrm{C}$. The whale is inferred to have slipped from the ice in three steps (I, II and III), thereby suffering only minor damage. 

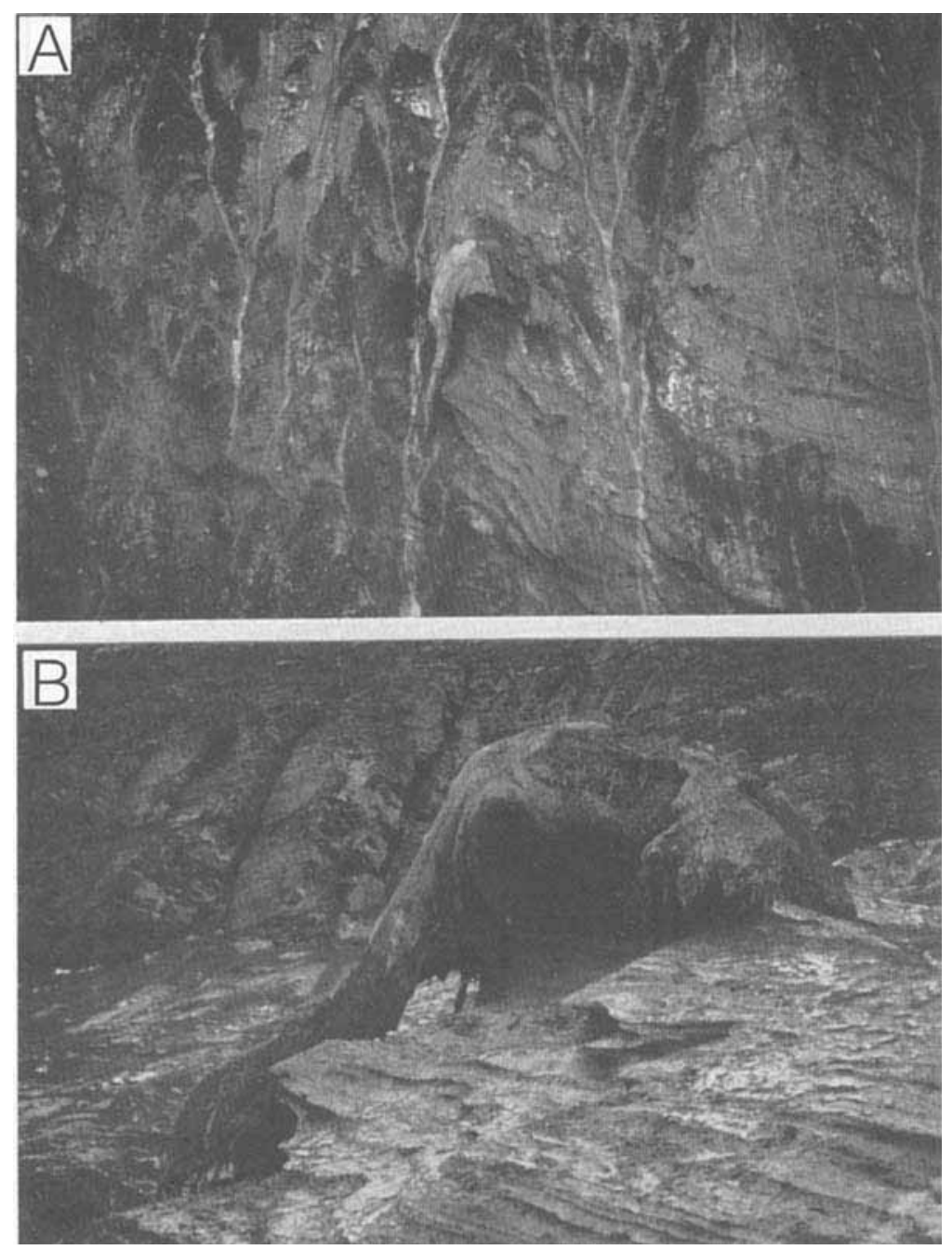

Fig. 4. A. Detail showing the shear planes surrounding the whale (here in position II, cf. Fig. 3C). Channelised

meltwater rivulets close to its posterior have caused this part to be released first (photo taken from helicopter) B. Close-up of the carcass (photo taken from the beach), showing the large tear and gravel-filled interior (photographs by V. Bakken).

cliff, $15 \mathrm{~m}$ a.s.1. (Fig. 1). Folded and sheared ice with diamictic sediment bands, both in the icecliff and in plan-view, show that this ice was formed by active glacier movement and thus morphologically represents a lateral moraine (Fig. 3A).

A few days before we arrived at the study area, the whale had been photographed from a helicopter while still partly embedded in the ice. At that time, the posterior part had melted out from the ice and the carcass hung from its anterior (Fig. 4A). When we arrived at the study area the whale had melted totally out of the ice and had slid down to the beach, evidently due to undercutting by meltwater rivulets on the ice surface. Remnants of skin tissue and some brownish colouring of the ice (Fig. 3B) indicated the whale's original position. A three-step release from the ice, including two rotational movements has been reconstructed (positions I-III, Fig. 3C). The whale had originally been oriented parallel with the relatively steep and curved flow lines as seen in the ice in Figs. $3 \mathrm{~B}$ and $4 \mathrm{~A}$, with the thinnest, posterior part dipping upflow (position I, Fig. 3C).

As the mouth region was partly missing and hidden under the carcass, the species could not be determined in the field. However, the size of the head compared to the length of the body and the 
Fig. 5. A. The $8 \mathrm{~m}$ long whale carcass on the beach. Note the preserved tail-part, holed and torn abdominal cavity and anterior part of the body. Frame shows location of closeup in Fig. 5B. B. Detail from the punctured gravel-filled abdominal cavity (see also roundness samples in Fig. 7B). The photograph also shows the red-brownish fibrous surface and remnants of gastrointestinal organs.
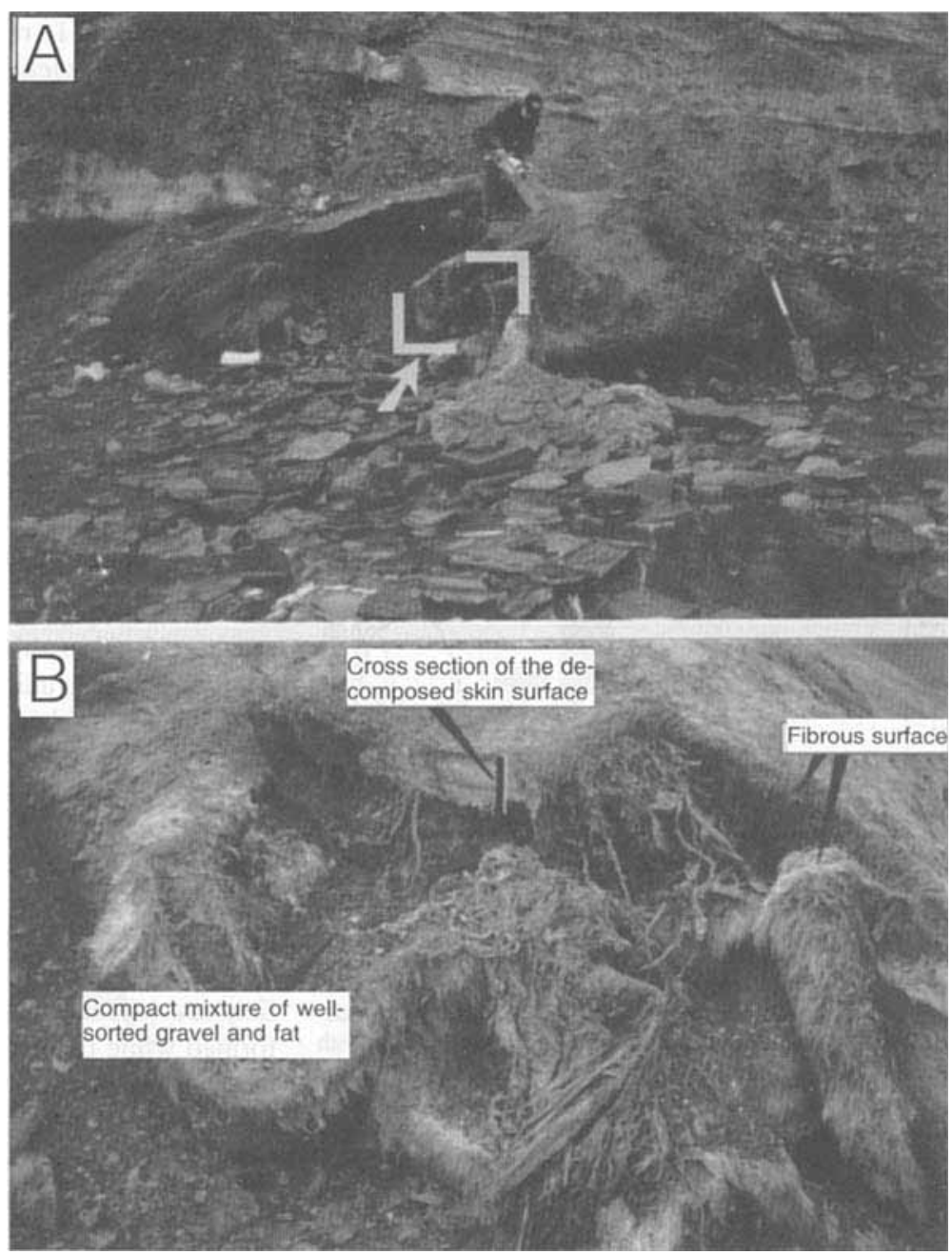

lack of a caudal fin, indicated a baleen whale. This assumption was supported by an analysis of muscle tissue which showed the characteristic DNA sequence of a bowhead whale (Balaena mysticetus) (C. Bendixen, pers. comm.). The bowhead whale calves are $4-4.5 \mathrm{~m}$ long at birth and adults are from 11-20 m long (Reeves \& Leatherwood 1989). The preserved tale-fluke and one orbit in the head (eye or ear?) suggest that the $8 \mathrm{~m}$ length measured in the field could be close to the full length of the animal. Although no tongue was found in the carcass, the characteristic large tongue of this species (up to $5.5 \mathrm{~m}$ long and $3 \mathrm{~m}$ wide on adults, Reeves \& Leatherwood 1989) would have increased the total length of the carcass.

The skin surface and blubber of the whale were highly decomposed, leaving a $9-19 \mathrm{~cm}$ thick compact fibrous crust covered by up to $10 \mathrm{~cm}$ long fibrous threads (Figs. 5A and B). The posterior part was best preserved, with both muscles and some blubber intact. Polar bears (Ursus maritimus) had been observed at the site few days before we arrived ( $V$. Bakken, pers. comm. 1996), but only minor pieces of bones and skin were observed scattered around on the beach. Two minor tears, one in the posterior and the other in the anterior part, may have formed as the 

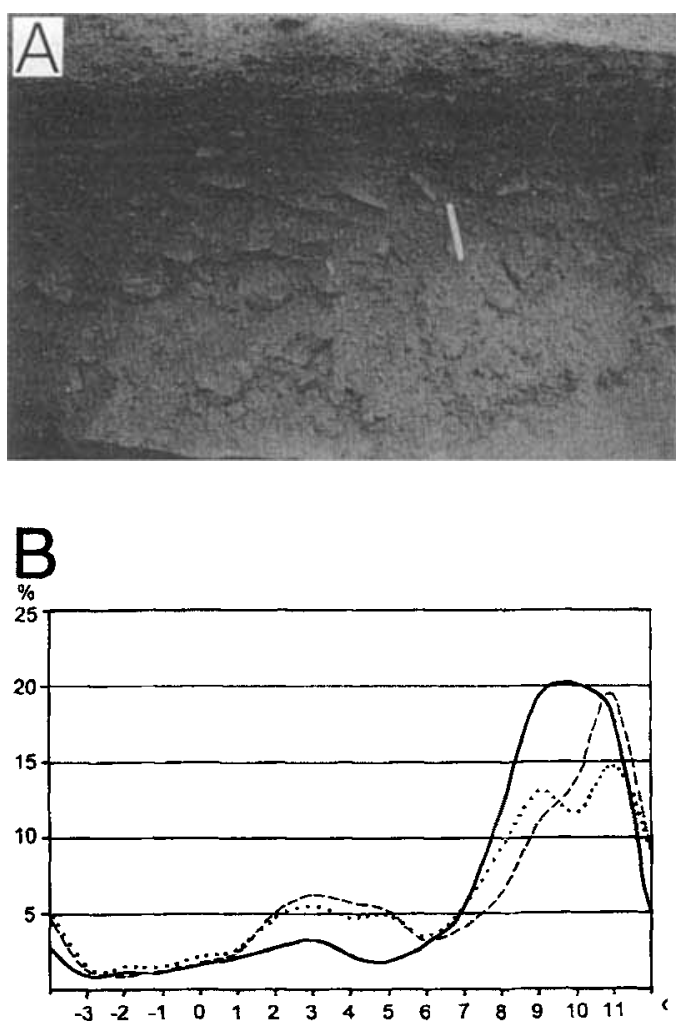

Fig. 6. A. Detail from a sediment band in the glacier ice, showing unsorted clast-bearing diamictic debris, with welldeveloped clast orientation (disc-shaped clasts) parallel with the foliation structures within the ice and with upflow imbrication (scale is $20 \mathrm{~cm}$ ). B. Grain-size distribution curve from diamictic sediments in shear planes (solid line). For comparison two samples from glaciers above the marine limit (stippled and dotted line, see text for discussion) are also shown.

body broke away from the glacier, as suggested by the tissue remnants in the ice-cliff (Fig. 3B). The largest tear (Fig. 4), which started at the dorsal part on the abdominal cavity and continued to the ventral side leaving part of the abdominal cavity open (probably with origin in the weaker moutharea), must have formed prior to glacial transport.

The abdominal wall was holed. Amphipods will normally break down carcasses rapidly in shallow water, although remnants of partly-preserved gastrointestinal organs indicate that this process was interrupted. The cavity was filled with a compact mixture of well-sorted gravel and fat as well as remnants of abdominal organs (Fig. 5B). The clast roundness of the gravel was measured using the Krumbein (1941) reference scale with
10 classes (Fig. 7C). Three grain-size fractions were chosen, $8-16 \mathrm{~mm}, 4-8 \mathrm{~mm}$ and $2-4 \mathrm{~mm}$, and the histograms clearly suggest a normal distribution with an average from the three fractions of $0.56,0.58$ and 0.54 , respectively (Fig. $7 \mathrm{~B}$ ).

\section{Radiocarbon dating}

The radiocarbon dating method (see Gulliksen 1980) was used for age determination, and a caudal vertebra was radiocarbon dated to $345 \pm 40{ }^{14} \mathrm{C}$ yrs BP (T-12701). Calibration of this age, using the curve from Stuiver \& Reimer (1993), yielded an age of 1535-1660 cal. AD.

\section{Southern lateral moraine}

The southern part of the southern lateral moraine reaches $40-60 \mathrm{~m}$ altitude along the coastline (with an increasing gradient inland). The whale was found in a lee-side position compared to the main valley walls, ca. $130 \mathrm{~m}$ from the southernmost limit of the moraine (see Fig. 3A). Oblique aerial photographs from 1936 (2493, Norwegian Polar Institute) clearly show that longitudinal sediment bands and shear planes within this topographically highest and inferred oldest part of the lateral moraine, curve southwards around the foot of the Schönrockfjellet mountain. They thus must have formed while the ice-front was located far outside the present coast-line. As shown by the former ice-front positions in Fig. 1, the last surge episode (maximum extent was close to the 1976-position) did not include the southernmost $1.3 \mathrm{~km}$ broad, triangular corner of the ice-front. This area has been inactive since ca. 1900 but has undergone some downwasting with the development of a lateral moraine.

A very thin debris layer covers the glacier ice in this part of the lateral moraine, accumulated as a result of the melting out of sediment bands in the ice, together with some input of scree deposits from the bedrock slopes as shown by a wedge of rock-fall debris onlapping the moraine (Fig. 3A). The southernmost $1 \mathrm{~km}$ of the moraine is undercut by waves, and the sediments which melt out are continuously being removed. The sediment cover is also being reworked by small rivulets of flowing water, both from the melting of ice and from the Schönrockfjellet mountain.

The main parts of this lateral moraine correlate with the ice-front mapped by Vasiliev et al. (1907, Fig. 1). However, the radiocarbon age of the carcass 

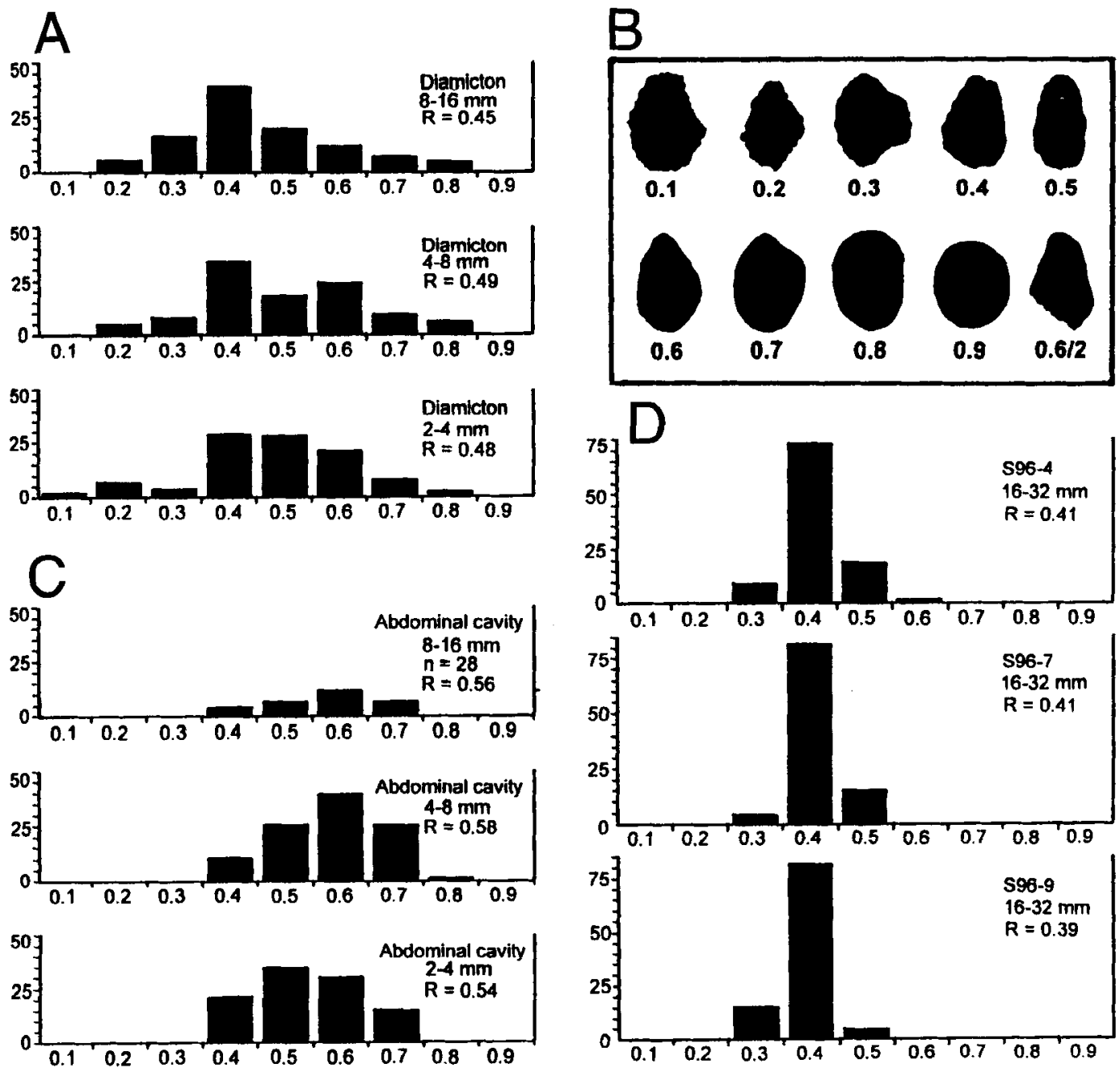

Fig. 7. Laboratory analyses of roundness. A. Three classes of bedrock clasts from diamictic sediment band in the glacier ice. B. Clasts from sorted gravel filling the whale carcass. C. Reference scheme (after Krumbein, 1941), with 10 classes. D. Three samples from lateral moraines at Nordenskiöldland (see text for discussion). $\mathrm{N}=100$ for all samples except in Fig. A, $>8 \mathrm{~mm}$.

indicate that older ice might be present (see discussion below). Based on the curvature of present ice-flow structures as seen on old photographs (36-2492, Norwegian Polar Institute), we suggest a slightly more extended position to the south (ca. $1 \mathrm{~km}$ as indicated in Fig. 1) compared to the one mapped by Vasiliev (either due to incorrect mapping or because the ice-front in 1900 had broken up compared to its maximum position).

The vertical ice cliff exposes internal deformation structures (Fig. 3A) with steeply folded ice in the area where the carcass was incorporated (Figs. $3 \mathrm{~B}$ and $4 \mathrm{~A})$ and a larger thrust-plane $100-150 \mathrm{~m}$ further north (up-flow) where the truncation of fold structures clearly shows an offset of several metres (Fig. 3A). Numerous up-flow dipping sediment-bands and sediment rich shear-zones are seen along the exposed ice-cliff and appear to continue to the top of the moraine, $40-60 \mathrm{~m}$ a.s.1. A detail from one of these sediment bands (Fig. 6A) shows a dominance of disc-shaped clasts (due to the shaley bedrock) with upflow imbrication.

Grain size analysis from this sediment (Fig. 6B) shows an unsorted, silty diamicton with a slightly bimodal grain-size distribution. Two sources are suggested for the high silt content: erosion of the 
shaley Cretaceous bedrock and entrainment of glaciomarine sediments. Two samples from a valley glacier at Nordenskiöldland (Lønne \& Lysaå, unpublished) are shown in the same diagram (Fig. 6B). This glacier erodes in Tertiary bedrock and these two samples are from lateral moraines formed well above the marine limit and thus exclusively comprise subglacially sorted debris. They display a bimodal distribution similar to the Jemelianovbreen sample.

Clast roundness from this shear-band diamicton (Fig. 6A) was measured using the same three grain-size fractions as the sample from the whale's abdominal cavity. An average of 0.45 , 0.49 and 0.48 was obtained for the three classes (see Fig. 7A). In comparison, three roundness samples from two valley glaciers on Nordenskioldland are shown. Despite the different clast size fraction measured on these samples $(16-32 \mathrm{~mm})$, the average is $0.41,0.41$ and 0.39 (Fig. 7D). These consistent roundness values from diamicton (0.39-0.49) differ from the higher roundness values of the gravel which fills the whale carcass $(0.54-0.58)$, suggesting that the well-rounded sediment in the whale carcass originated from a beach, most likely having been washed in by strong waves. As shown in Fig. 4 this gravel was filled in prior to the glacial transport. We conclude that the carcass must have been lying on the beach or in shallow water when it was overridden by the glacier.

Findings of black-coloured baleens in a sediment band in the ice, $2 \mathrm{~m}$ a.s.l. and $60 \mathrm{~m}$ south of the carcass site (Fig. 3A) as well as other whale bones, shell fragments, and a walrus tooth in these sediment bands, clearly demonstrates that large volumes of glaciomarine sediments have been incorporated into the ice by subglacial compressive shear.

\section{Discussion}

Decomposition of the skin surface and blubber, the penetration of the abdominal cavity and some major tearing, were clearly visible while the whale was still embedded in the ice (Fig. 4), and must therefore have formed before the whale was entrained by the advancing glacier. We conclude that the carcass was picked up from the beach or shallow water, also supported by finds of wellrounded gravel in the abdominal cavity. A carcass lying on the beach would quickly have been preyed upon by carnivores such as the arctic fox (Alopex lagopus) and polar bear (Chesemore 1968; Hansson et al. 1990). If the whale stranded in shallow water, it would have been protected from carnivores but subject to immediate attack by amphipods. The partly preserved gastrointestinal organs and blubber indicate that the carcass must have been incorporated into the glacier shortly after death. Right whales (Balaenidae) have a thick crust of blubber, and they are filled with natural gasses when they die, making the carcasses float. Since the posterior section of this whale was better preserved, this part may have been covered (by ice, snow, sediments and/or icebergs/glacier ice) and thus protected from predators and wave erosion. We conclude that some of the minor tears in the tale and mouth areas occurred as the carcass was melting out from the ice (Fig. 3C).

Only minor damage seems to have occurred during the glacial transport (except for larger bones being broken). An old carcass melting out from snow or ice would thaw and deform more readily than a relatively fresh carcass, due to putrefaction. It is thus most likely that this relatively well-preserved carcass was found in ice which was active at the time when the carcass was entrained from the beach or shallow sea. Even if also other species of baleen whales have dark baleens (Ridgeway \& Harrison 1989), the baleen found $60 \mathrm{~m}$ south of the carcass most likely originates from the same individual, thus supporting the idea that the whale remnants and the ice have the same age.

The reported age of $345 \pm 40{ }^{14} \mathrm{C}$ years $\mathrm{BP}$ includes a standard marine reservoir correction of age of -440 years. In the calibrated age, a reservoir correction for the Svalbard region of -550 is used (cf. Mangerud \& Gulliksen 1975). Recent results from the Canadian Arctic (Dyke et al. 1996) suggest that the carbon in bowhead collagen appears to derive from the zooplancton food rather than from marine bicarbonate, thus, a reservoir age of -200 could be more correct. These data remain to be verified from other areas. However, we consider the reported age to be a minimum age.

Two models are discussed in this paper for the presence of ca. $350{ }^{14} \mathrm{C}$ year-old glacier ice along the margin of Jemelianovbreen basin: (1) The ice became part of a lateral moraine at the foot of Schönrockfjellet ca. 350 years ago, has been 
protected against melting by a debris cover, and also survived the most extensive surge around 1900. (2) The whale was entrapped in glacier ice further west in the basin 345 years ago. Due to vertical thinning of the glacier, the ice along the basin margins developed into a lateral moraine, and this ice, containing the whale carcass, was further reactivated during the surge of $1900 \mathrm{AD}$ and displaced to its present position.

Today, the southernmost part of the lateral moraine is $40-60 \mathrm{~m}$ high. The distance from the foot of the mountain to the present ice-cliff which is constantly being abraded by the sea, is estimated roughly to a maximum of a few tens of metres. There are no known ice front advances which could have activated this ice after 1900 $\mathrm{AD}$, which means that the ice is at least 90 years old. This remnant ice is rapidly decreasing in size during the present climate, and in a few decades it will most likely have melted. We therefore consider the preservation potential for ice-remnants along the east-facing foot of the Schönrockfjellet to be relatively low, probably lasting in the order of 100 years with the present climate, and a little longer with a slightly colder climate.

The model 2 alternative, that this ice was part of a lateral moraine along the north-facing side of the Jemelianovbreen basin, would imply a higher preservation potential of the ice due to lower insolation and the lack of marine abrasion. Such an ice remnant would easily be reactivated with growth of the Jemelianovbreen glacier and eastward advance into the marine embayment. We find the last model most attractive, although we cannot exclude the first one.

Because the whale stranded on a beach, the glacier had a smaller extent than present. Further, the whale is clearly transported out of the basin by a glacier with an extent of similar scale as the $1900 \mathrm{AD}$ advance. We have evidence for glacier advancement over a soft, deformable substrate, and compressive shear movement with relatively large volumes of glaciomarine sediment incorporated into the ice. This indicates a glacier which is not frozen to its bed. The radiocarbon dating suggests that the whale was incorporated some time during the Little Ice Age period. A stable isotopic record from a $200 \mathrm{~m}$ long ice core from the Lomonosov ice plateau in east-central Svalbard (Gordiyenko et al. 1980) showed two cold periods, one between 1200 and $1500 \mathrm{cal}$. AD and the second between 1700 and $1900 \mathrm{cal}$. AD. Similar results were obtained from sediment cores from the lake Linnevannet at the west coast of Svalbard, showing that the first cold period culminated ca. $1400 \mathrm{cal}$. $\mathrm{AD}$ and the second occurred after 1500 cal. AD (Svendsen \& Mangerud 1997). It is well known that tidewater glacier termini may vary, unrelated to climatic changes (Mercher 1961; Mann 1986), however, we also know that two surge episodes have occurred in this glacial basin. Most surges, but not all, seem to occur at regular intervals (Paterson 1994). Jemelianovbreen may have a surging period of ca. 80 years, which means 4-5 times during the last ca. 350 years. The last surge in 1971 did not include the entire width of the ice front; the southernmost corner was left inactive. A surge may also reactivate stagnant ice (see Raymond et al. 1987). We have no conclusive evidence that the advance episode which entombed the whale carcass was a surge, but its not unlikely. During a surge, the ice will move as a block, gliding on the bed, but compression will occur at the front.

Interestingly, a similar story was reported by Dineley \& Garrett (1959). Remains of a whale, with bones, flesh and skin partly preserved, were found in the ice-cored moraine of the Sveabreen glacier in Ekmanfjorden at Svalbard (see Fig. 1, inset map). The frontal part of the whale was missing, but it's original length was estimated to more than $20 \mathrm{~m}$. It was found together with the thermophilous mollusc Mytilus edulis, which is extinct in the Svalbard region today. Sveabreen is also a tidewater glacier, but no surge-activity has been documented (Hagen et al. 1993). Based on the presence of Mytilus, Dineley \& Garrett (1959) concluded that the whale was incorporated during an ice front advance some time during the last climatic optimum which was inferred to be ca. 2500 years BP. Recent investigations suggest that Mytilus was present on Svalbard from 9500 to $3500{ }^{14} \mathrm{C}$ BP and probably reappeared shortly around 1000 years BP (Salvigsen et al. 1992). Alternatively, Mytilus in Sveabreen was reworked from the sea floor or older beach sediments, and the ice-front advance was much younger.

\section{Conclusion}

The partly decomposed carcass of an $8 \mathrm{~m}$ long bowhead whale was entrained into the Jemelianovbreen glacier from the beach or shallow water 


\section{I. Lanne \& E. Fuglei}

during an advance episode. The whale was lifted $15 \mathrm{~m}$ above present sea level. Diamictic sediment bands including remnants of different marine organisms were found in this lateral moraine up to $40-60 \mathrm{~m}$ a.s.1., suggesting that a relatively large volume of unconsolidated glaciomarine sediments were actively sheared into the glacier. Radiocarbon-dating yields $345 \pm 40{ }^{14} \mathrm{C}$ years $\mathrm{BP}$ (1535-1660 cal. AD), suggesting that this ice front advance took place during the last part of the Little Ice Age cold period.

Acknowledgements. - The whale finding was reported in August 1996 by the Alaskan paddling expedition J. Fredston, D. Fesler and J. Bauman. J. E. Guldahl and S. Onarheim assisted in field. Radiocarbon date was analysed by the Laboratory for Radiological Dating, NTNV, Trondheim, Norway, and DNA by the Danish Institute of Animal Science, Tjele, Denmark. Valuable comments to the manuscript were given by $\mathrm{O}$. Salvigsen, H. Björnsson and D. Griffiths.

\section{References}

Chesemore, D. L. 1968: Notes on the food habits of Arctic foxes in northern Alaska. Can. J. Zool. 46, 1127-1130.

Dallmann, W. K., Winsnes, T. S. \& Birkenmajer, K. 1993: Geological map. Kvalvå̊gen C11G, Norsk Polarinstitutt, Oslo.

Dineley, D. L. \& Garrett, P. A. 1959: Whale remains in glacier ice. Nature $183,272$.

Dyke, A. S., McNeely, R. N. \& Hooper, J. 1996: Marine reservoir corrections for bowhead whale radiocarbon age determinations. Can. J. Earth Sci. 33, 1628-1637.

Forman, S. L. 1990. Post-glacial relative sea-level history of northwestern Spitsbergen, Svalbard. Geol. Soc. Am. Bull. $102,1580-1590$.

Gordiyenko, F. G., Kotlyakov, V. M., Punning, Ya.-M. M., and Vairmäe, R. 1980: Study of a $200 \mathrm{~m}$ core from the Lomonosov Ice Plateau in Spitsbergen and the paleoclimatie implications. Polar Geogr. Geol. 5, 242-251.

Gulliksen, S. 1980: Isotopic fractionation of Norwegian material for radiocarbon dating. Radiocarbon 22, 980-986.

Hagen, J. O., Liestøl, O., Roland, B. \& Jørgensen, T. 1993: Glacier Atlas of Svalbard and Jan Mayen. Medd. 129, Norsk Polarinstitutt, Oslo.
Hansson, R., Prestrud, P. \& Øritsland, N. A. 1990: Polar bear. In: Assessment system for the environmental and industrial activities in Svalbard. Norsk Polarinst. Rep. 68, 59-70.

Krumbein, W. C. 1941: Measurement and geological significance of shape and roundness of sedimentary particles. $J$. Sediment. Petrol. 11, 64-72.

Lefauconnier, B. \& Hagen, J. O. 1991: Surging and calving glaciers in eastern Svalbard. Medd. 116, Norsk Polarinstitutt, Oslo, $130 \mathrm{pp}$.

Mangerud, J. \& Gulliksen, S. 1975: Apparent radiocarbon age of recent marine shells from Norway, Spitsbergen and Arctic Canada. Quat. Res. 5, 263-273.

Mann, D. H. 1986: Reliability of a fjord glaciers's fluctuations for paleoclimatic reconstructions. Quat. Res. 25, 10-24.

Mercher, J. H. 1961: Response of fjord glaciers to change in fim limit. J. Glaciol. 3, 850-858.

Paterson, W. S. B. 1994: The physics of glaciers. Pergamon Press, 3rd edition, $480 \mathrm{pp}$.

Raymond, C. F., Jóhannesson, T., Pfeffer, T. \& Sharp, M. 1987: Propagation of a glacier surge into stagnant ice. J. Geophys. Res. 92, 9037-9049.

Reeves, R. R. \& Leatherwood, S. 1989: Bowhead Whales Balaena mysticetus Linneaus, 1758. Pp. 305-344 in Ridgway, S.H. \& Harrison, R. J. (eds.): Handbook of Marine Mammals. Vol 3: The Sirenians and Baleen Whales. Academic Press, London.

Ridgway, S. H. \& Harrison, R. J. 1989: Handbook of Marine Mammals. Vol 3: The Sirenians and Baleen Whales. Academic Press, London, $362 \mathrm{pp}$.

Salvigsen, O. 1978: Holocene emergence and finds of pumice, whalebones, and driftwood at Svartknausflya, Nordaustlandet. Norsk Polarin. Årbok 1997, 217-228.

Salvigsen, O., Forman, S. L. \& Miller, G. H. 1992: Thermophilous molluscs on Svalbard during the Holocene and their paleoclimatic implications. Polar Res. 11, 1-10.

Stuiver, M. \& Reimer, P. J. 1993; Extended ${ }^{14} \mathrm{C}$ data base and revised CALIB $3.0^{14} \mathrm{C}$ age calibration program. Radiocarbon 35, 215-230.

Svendsen, J. I. \& Mangerud, J. 1997: Holocene glacial and climatic variations on Spitsbergen, Svalbard. The Holocene $7,45-57$.

Vasiliev et al. 1907: Missions Scientifiques pour la Mesure d'un arc de Méridien au Spitsberg enteprises en 1899-1902 sous les auspices des gouvernements Russe et Suédois. Mission russe: Imprimerie Impériale des Sciences, St. Petersbourg. 